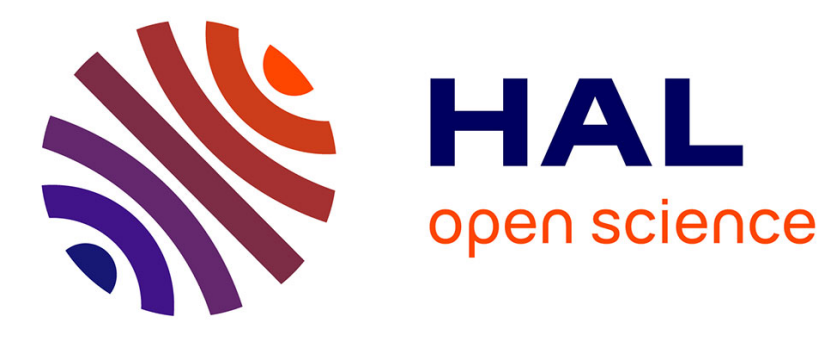

\title{
TUNABLE DIODE-PUMPED-LNA LASER
}

\author{
A. Cassimi, Vincent Hardy, J. Hamel, M. Leduc
}

\section{To cite this version:}

A. Cassimi, Vincent Hardy, J. Hamel, M. Leduc. TUNABLE DIODE-PUMPED-LNA LASER. Journal de Physique Colloques, 1987, 48 (C7), pp.C7-351-C7-353. 10.1051/jphyscol:1987784 . jpa00227088

\section{HAL Id: jpa-00227088 https://hal.science/jpa-00227088}

Submitted on 1 Jan 1987

HAL is a multi-disciplinary open access archive for the deposit and dissemination of scientific research documents, whether they are published or not. The documents may come from teaching and research institutions in France or abroad, or from public or private research centers.
L'archive ouverte pluridisciplinaire HAL, est destinée au dépôt et à la diffusion de documents scientifiques de niveau recherche, publiés ou non, émanant des établissements d'enseignement et de recherche français ou étrangers, des laboratoires publics ou privés. 
JOURNAL DE PHYSIQUE

Colloque $\mathrm{C7}$, supplément au $\mathrm{n}^{\circ} 12$, Tome 48, décembre 1987

TUNABLE DIODE-PUMPED-INA LASER

\author{
A. CASSIMI, V. HARDY, J. HAMEL and M. LEDUC* \\ Laboratoire de Spectroscopie Atomique, ISMRa-Université de \\ Caen, F-14032 Caen Cedex, France \\ * Laboratoire de Spectroscopie Hertzienne de I'ENS, 24, Rue \\ Lhomond, F-75231 Paris Cedex 05, France
}

\begin{abstract}
Diode-pumped crystals provided recently new compact laser devices. We report the first end pumping of a $\mathrm{La} \mathrm{Nd} \mathrm{MgAl}_{11} \mathrm{O}_{19}$ (LNA) crystal using a $200 \mathrm{~mW}$ diode array (Spectra Diode Lab). We also report the first results obtained with a $1 \mathrm{~mW}$ diode (SONY). This C.W. laser can be tuned from $1.048 \mu \mathrm{m}$ to $1.086 \mu \mathrm{m}$.

Without selective elements in the cavity, the laser emits around $1.054 \mu \mathrm{m}$ with a threshold of $24 \mathrm{~mW}$ and a slope efficiency of $4.4 \%$ (output mirror of transmission $T=1 \%$ ) when pumped by the diode array. With the selective elements, the threshold increases to $100 \mathrm{~mW}$ and we obtain a power of $4 \mathrm{~mW}$ for a pump power of $200 \mathrm{~mW}$.
\end{abstract}

Diode-pumped solid laser materials provide highly efficient as well as compact and relatively low cost laser devices leading to a wide range of potential applications [ $\left.{ }^{1}\right]$ : End pumping of $\mathrm{Nd}$ :YAG cystals can deliver over 100mW of continuous power at $1.06 \mu \mathrm{m}$ when pumped with diode arrays $\left[{ }^{2}\right]$, the overall wall-plug efficiency being as large as $8 \%\left[{ }^{1}\right]$. There is now a rapidly increasing number of neodymium doped material which has been shown to lase under diode excitation such as $\mathrm{LiNbO}_{3}\left[\left[^{1]}\right]\right.$ or silica fibers $\left[{ }^{4}\right]$. Here we report the diode pumping of La $\mathrm{Nd}_{1-\mathrm{MgAl}_{1} \mathrm{O}_{19}}$ (LNA) $\left[{ }^{5,6}\right]$ which is a crystal with laser characteristics similar to Nd:YAG or Nd:YAP $\left[{ }^{7}\right]$ although with different crystalline symmetry. We also report the ability to tune the LNA laser output within the range $1.048 \mu \mathrm{m}-1.086 \mu \mathrm{m}$.

An important difference between LNA and YAG is the Nd concentration, which can be higher in LNA than in YAG without quenching of the fluorescence $\left[{ }^{5}\right]$. This could be an advantage for future high power lasers. LNA was recently found to be a slighţly tunạble infra-red laser with an efficiency comparable to YAG when excited by $\mathrm{Ar}^{+}$of $\mathrm{Kr}^{+}$lasers $\left[{ }^{8,9}\right]$. It oscillates at wavelengths significantly different from YAG, with a main peak around $1.054 \mu \mathrm{m}$ and two other weaker peaks around $1.065 \mu \mathrm{m}$ and $1.082 \mu \mathrm{m}$. The laser band around $1.065 \mu \mathrm{m}$ had not been observed earlier. It corresponds to a weak fluorescence band actually observed in $\left[{ }^{5}\right]$ and $\left[{ }^{9}\right]$.

The LNA crystal ia s cylinder, $5 \mathrm{~mm}$ in diameter and $5 \mathrm{~mm}$ in length, grown in LETI (Grenoble). The -rod axis coincides with the crystalline c-axis. One of the two polished parallel faces is high reflectivity coated for the laser radiation and high transmission coated for the pump radiation. The other is antireflection coated for $\lambda \simeq 1.06 \mu \mathrm{m}$. It is excited longitudinally by a $C . W$. diode focused on one end of the crystal. The set-up is shown in figure 1 .

The diode emits at $800 \mathrm{~nm}$, wavelength within the absorption band of $\operatorname{LNA}\left[{ }^{5} .9\right]$ The light emitted by the diode is collimated by corrected lenses of large aperture (Melles Griot 06 GLC 002). 
To convert the diode output beam to a near-circular one, we use an amorphic

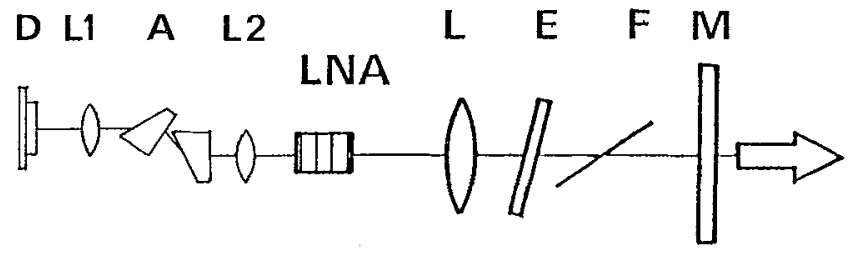

Fig. 1 : Cavity used for the LNA laser pumped by a laser diode

prism pair. Then we focus it on the crystal through a lens of focal length $10 \mathrm{~mm}$. The laser cavity consists of the high reflectivity coated face of the crystal and a plane output mirror $M$ of low transmission $T=1 \%$ associated vith an $A R$ coated lens $\mathrm{L}$ of focal length $25 \mathrm{~mm}$. The total cavity length is approximately $13 \mathrm{~cm}$. the transverse waist of the gaussian beam in this cavity is of the order of $100 \mu \mathrm{m}$, matching the pump spot size.

Fig. 2 : Output power of the LNA laser

(at $1.054 \mu \mathrm{m}$ ) as a function of the pump power on the crystal.

The two lines are for different laser diodes : SDL $2420 \mathrm{H} 1$ diode array (200mW) ---- SLD $304 \mathrm{~V}$ diode

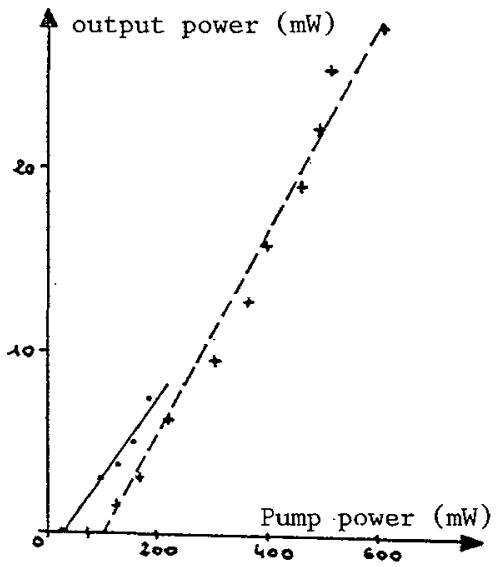

The results are shown in fig. 2 without selective elements in the cavity the LNA laser emits on the main fluorescence peak at $1.054 \mu \mathrm{m}$. The output power is plotted as function of the pump power on the crystal, which absorbs $80 \%$ of the incident light when pumped by a diode array (model $2420 \mathrm{H} 1$ from Spectra diode lab) delivering $200 \mathrm{~mW}$. The threshold is $24 \mathrm{~mW}$ and the slope efficiency $5,5 \%$ (emitted power/ absorbed power).

Pumping by a demonstration diode SONY emitting $1 \mathrm{~W}$ around $80 \mathrm{~mm}$ has been briefly tried $\left[{ }^{10}\right]$ (model SLD 304V). The crystal absorbed $73 \%$ of this radiation. The threshold was $70 \mathrm{~mW}$ and the slope efficiency $7,4 \%$ (emitted power/absorbed power). [The interfacing of the diode and the focusing optics was not optimized].

Tuning the frequency of the LNA laser was achieved by inserting a single plate birefringent Lyot filter $F$ (a $1 \mathrm{~mm}$ thick quartz plate) at Brewster angle in the cavity. Oscillation on the main peak at $1.054 \mu \mathrm{m}$ could be suppressed and tuning around $1.082 \mu \mathrm{m}$ was then posible. Fine tuning was accomplished with a thin, solid etalon $E$ (a $100 \mu \mathrm{m}$ non coated plate of fused silica). The observed laser emission when pumped with a $200 \mathrm{~mW}$ diode array is shown in $\mathrm{fig} .3$.

Pumped by two $200 \mathrm{~mW}$ diode arrays coupled through a polarizing beam splitter or pumped by the $1 \mathrm{~W}$ diode (SONY), we can tune the laser on any of the wavelengths within the range $1.048 \mu \mathrm{m}-1.086 \mu \mathrm{m}$. The laser beam is linearly polarized according to the Lyot filter orientation. 


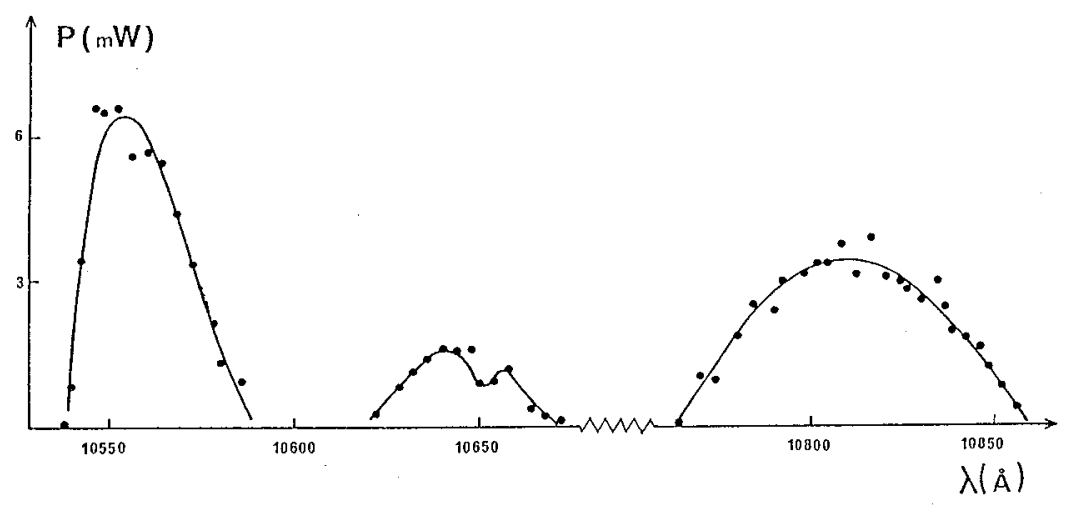

Fig. 3 : Output power of theLNA as a function of the wavelength. The pump power on the crystal is about $200 \mathrm{~mW}$.

In conclusion, LNA crystals can lase when pumped by diode, thus providing potentially a compact tunable source for atomic physics experiments.

\section{REFERENCES}

$\left.{ }^{1}\right]$ T. BAER, Laser Focus, pp 82-92, June 1986.

$\left[{ }^{2}\right]$ T. BAER, Report at the CLEO conference San Francisco (June 1986).

$\left.{ }^{3}\right]$ D.L. SIPES App. Phys. Lett. 47, 74 (1985).

$\left[{ }^{4}\right]$ R.J. MEARS, L. RECKIE, S.B. POOK and D.N. DAYNE, Electron. Lett. 22 (1986) 159.

$\left.{ }^{5}\right]$ K.S. BAGDASAROV, L.M. DOROZHKIN, L.A. ERMAKOVA, A.M. KEVORKOV, Yu.I. KRASILOV, N.T. KUZNETSOV, I.I. KURATOV, A.V. SHESTAKOV, Sov. J. Quantum Electron. 13, 1082 (1983).

$\left[{ }^{6}\right]$ V.M. GARMASH, A.A. KAMINSKII, M.I. POLYAKOV, S.E. SARKISOV and A.A. FILIMONOV, Phys. Status Solidi (a), 75, K111 (1983).

[ $\left.{ }^{7}\right]$ G.A. MASSEY and J.M. YARBOROUGH, App1. Phys. Lett. 18, 576 (1971)

$\left.{ }^{8}\right]$ D. VIVIEN, A.M. LEJUS, J. THERY, R. COLLONGUES, J.J. AUBERT, R. MONTCORGE and F. AUZEL, C.R. Acad. Sci. 298. 195 (1984).

$\left[{ }^{9}\right]$ L.D. SCHEARER, M. LEDUC, D. VIVIEN, A.M. LEJUS and J. THERY, IEEE J. of Quantum Electr. QE22, 713 (1986).

$\left[{ }^{10}\right]$ The authors thank $\operatorname{Dr} A$. BRILLET for his assistance permitting the experiment.

[ $\left.{ }^{11}\right]$ T.Y. FAN, A. CORDOVA-PLAZA, M.J.F. DIGONNET, R.L. BYER and H.J. SHAW, Journ. Opt. Soc. of Am. B $\underline{3}, 140$ (1986). 